\title{
EFFECT OF INFILL WALL ON RC FRAMED STRUCTURES
}

\author{
Harshavardhan B Sindol ${ }^{1}$, Rajendrakumar S Harsoor ${ }^{2}$ \\ ${ }^{I}$ M.Tech Scholar, Department of Civil Engineering, PDA College of Engineering, Kalaburagi, Karnataka, India \\ ${ }^{2}$ Professor and Dean, Department of Civil Engineering, PDA College of Engineering Kalaburagi, Karnataka, India
}

\begin{abstract}
This paper is concerned with study of effect of infill walls on R.C framed structures. Reinforced concrete (RC) frame buildings with masonry infill walls have been widely constructed for commercial, industrial and multi storey residential building. Masonry infill walls, typically consists of bricks or concrete blocks constructed between beams and columns of a reinforced concrete frame. The purpose of this analysis is to study the behavior of RC structure especially when it is subjected to seismic loads. A comparative study is carried out with RC building using Equivalent Lateral Force method, Response Spectrum analysis and time history analysis. In the present study, G+14 R.C.C framed building models is considered and analysed using ETABS software. Equivalent static method and Response Spectrum method of analysis has been used on the building, for analysis as per IS 1893:2002 and results obtained from the analysis are compared. Model analysis is carried out for medium soil and resulting displacement and drift are obtained. Time history analysis is done for all models. Results obtained are compared. The results of these models shows that, infill wall decreases the displacement of the structure and infill wall with opening has higher displacement when compared to infill wall without opening. Drift increases where infill is not provided.
\end{abstract}

Keywords: RC Framed Building, Infill Wall, Response Spectrum Analysis, Time History Analysis, Equivalent Static Analysis, ETABS V. 13.1

\section{INTRODUCTION}

Earthquake are the most dangerous natural hazards where both economy and life losses have occured. Due to sudden discharge of energy in earth's lithosphere, the ground shakes and earthquake will occur. This energy primarily emerges from stresses built up during tectonic processes that consist of interaction between the crust and the interior of the earth. A large portion of the misfortunes are because of building collapses or damages. Thus, it is essential to plan the structures to resist, moderate to serious Earthquake Ground Motions depending on its site area and significance of the structure. The retrofitting of building is essential if the present structure is not planned for earthquake.

Common practice of building design considers infill walls as non-structural element and building is designed as framed structure without considering structural action of infill walls. The soft storey effect and presence of infill in any building changes the behaviour of frame action due to relative changes of stiffness and lateral load distribution mechanism and thus may induce changes in phenomenon like lateral displacement and inter-storey drift.

Masonry infills which are said as non-structural elements, their stiffness contributions are generally ignored in practice. Such an approach can lead to an unsafe design. The masonry infill walls though constructed as secondary elements behaves as a constituent part of the structural system and determine the overall behaviour of the structure especially when it is subjected to seismic loads.

Lateral loads are forced on structures. To resist lateral loads, structures need a resisting system. Normally seismic forces or wind cause these loads. Consideration of lateral forces because of seismic loading or wind is essential for tall structures. The lateral load resistance necessity governs the design of tall structure along with gravity load.

\section{LITERATURE REVIEW}

Venkatesh S.V et al. (2010) examined the structural behavior of single-bay-four-bays, 10 storey RC frames given with masonry infill and steel bracings as lateral load resisting system (LLRS). The detailed examinations were done for zone V. Four models were analyzed comprising of one basic moment resisting $\mathrm{RC}$ frame and other three include basic moment resisting RC frame with Masonry Infill, External and Internal Steel Bracings. The outcomes acquired were completely researched for most extreme estimations of support reactions, column forces, beam forces and dynamic properties.

From the results obtained it was observed that the building provide better resistance to lateral load in the presence of LLRS. The most effective performing LLRS among the three LLRS thought of was Inner Steel Bracings as all the parameters considered lesson for this situation when compared with bare frame. Provision of LLRS adequately reduces large displacements found in bare frame.

Mrugesh D. Shah (2011) did a performance based seismic analysis of RCC frames, where two structures were considered for investigation. For the examination $\mathrm{G}+4$ and $\mathrm{G}+10$ reinforced concrete structures was demonstrated. Distinctive modeling problems were consolidated over 9 models for $\mathrm{G}+4$ and $\mathrm{G}+10$ building were; bare frame (without infill), having infill as membrane, replacing infill 
as an equivalent strut. The results are compared for all models. Comparative study was made for bare frame, replacing infill as an equivalent strut, having infill as layer. From the outcomes it had been noted that bare frame with infill has high lateral load capacity when compared to the bare frame without infill. Additionally bare frame with infill has small lateral load capacity when compared with bare frame with equivalent strut. He also concluded that increase in the number of bays, increases the lateral load carrying capacity. However increase in number of bays does not increase the corresponding displacement

M. V. Renukadevi, Niranjan C.B., and K.S.Jagadish (2012): In their study on nonlinear analysis of infilled frame says that, their main aim study is to find the variation of lateral stiffness and principal compressive diagonal strut width in infill structure. Both structures with openings and without openings were considered. Since non-linear analysis is more realistic, non-linear (multi-linear) analysis is performed in their study. Analysis performed using ANSYS Version 10.0. It is observed that linear analysis over estimates lateral stiffness of the infill frame. It is also observed that, width of compressive diagonal strut commonly decreases with increase in modulus of masonry infill. Also observed that, the frame with larger width of openings exhibits more initial lateral stiffness increase of two frames with equal area of openings because of possibility of formation of single diagonal strut.

\section{METHODOLOGY}

The modeling and analysis of building is carried out using ETABS software.

- Linear static method

- Response spectrum method

- Time History analysis

\section{Structural Modelling}

\section{Materials}

$\begin{array}{ll}\text { Concrete } & \text { M25 grade } \\ \text { Steel } & \text { HYSD } 415 \text { grade }\end{array}$

\section{Dimensions}

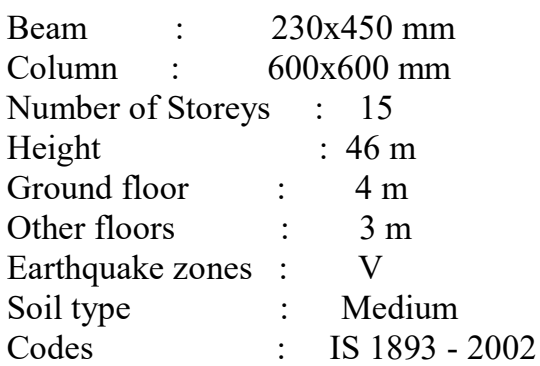

\section{TYPES OF MODELS:}

1. Infill wall without opening

2. Infill wall with opening

3. Infill wall at different stories

4. Infill wall of plus shape (plan) without opening

5. Infill wall of plus shape (plan) with opening

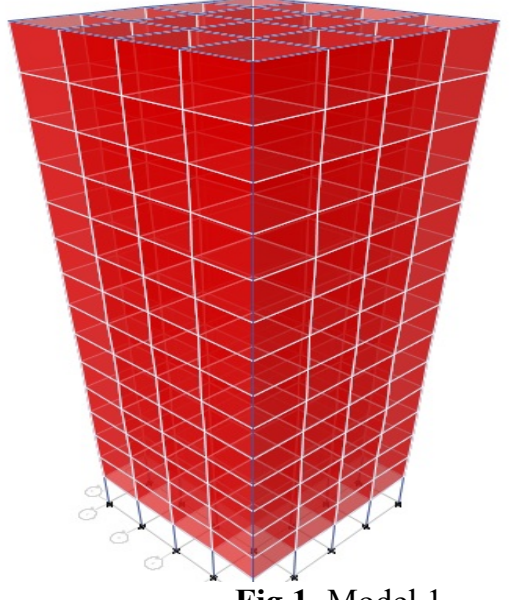

Fig.1. Model 1

(Infill wall without opening)

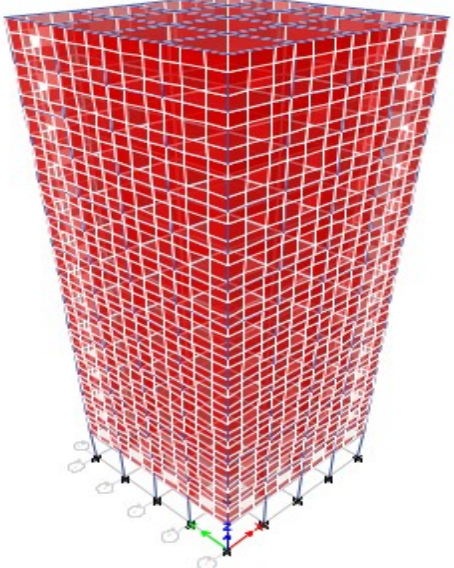

Fig.2. Model 2

(Infill wall with opening)

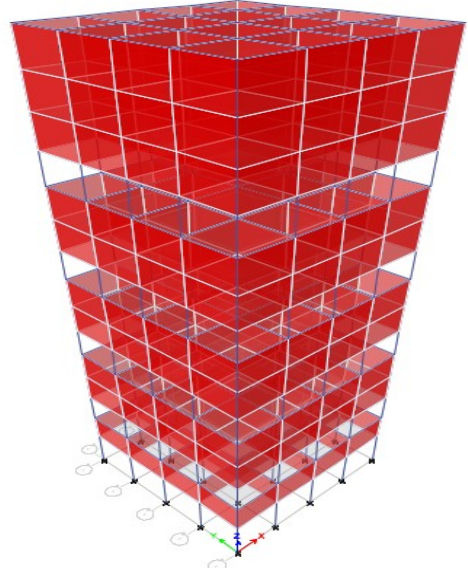

Fig.3. Model 3

(Infill wall at different stories) 


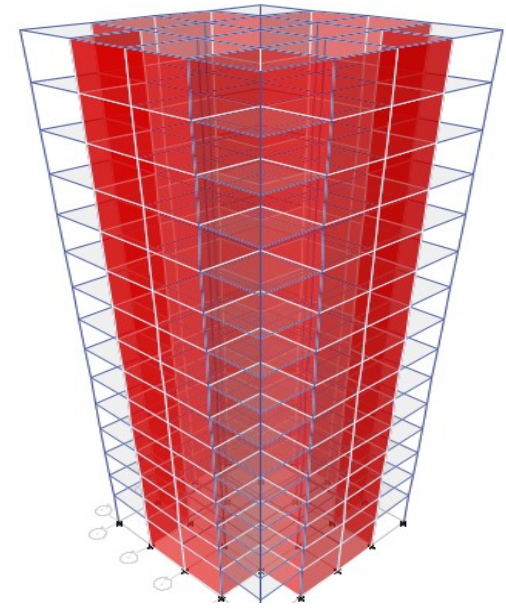

Fig.4. Model 4

(Infill wall of plus shape( plan) without opening)

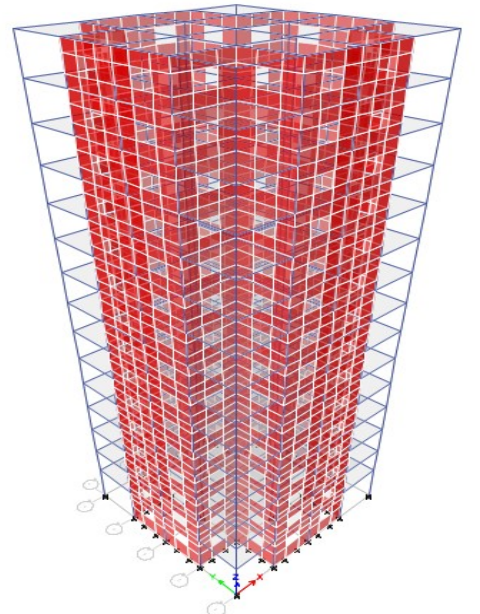

Fig.5. Model 5

(Infill wall of plus shape (plan) with opening)

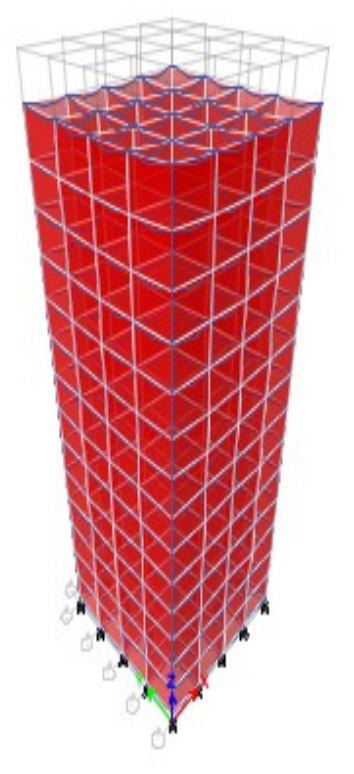

Fig.6. 3D deflection view of Infill wall without opening

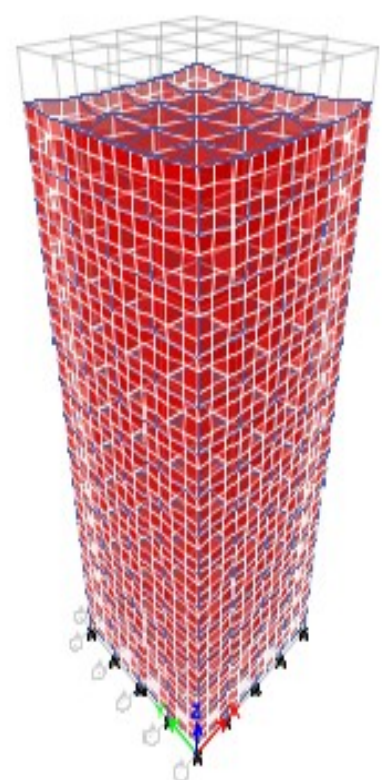

Fig.7. 3D deflection view of infill wall with opening stories

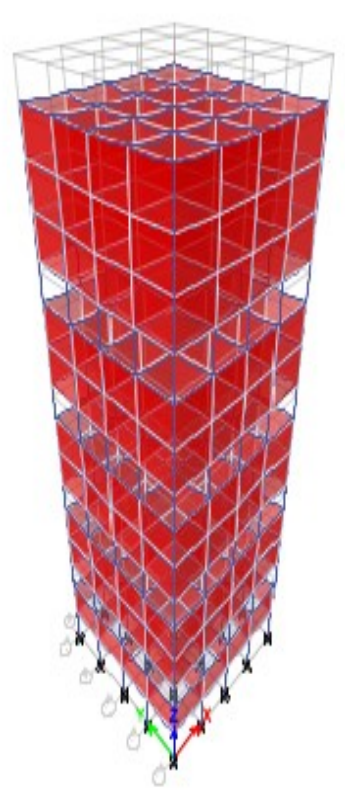

Fig.8. 3D deflection view of infill wall at different 


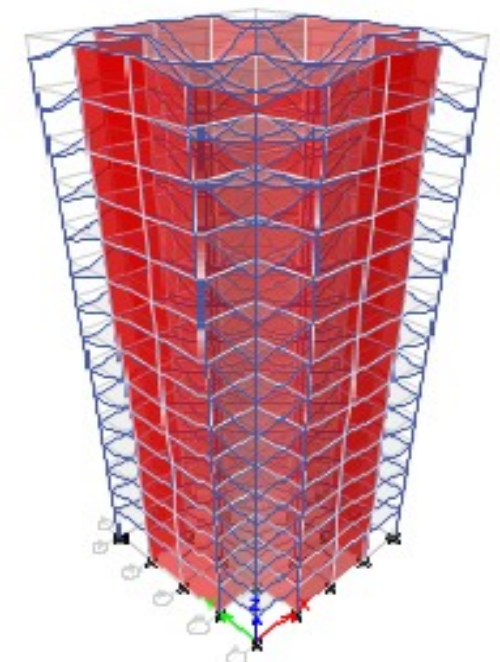

Fig.9. 3D deflection view of infill wall of plus shape (plan) without opening

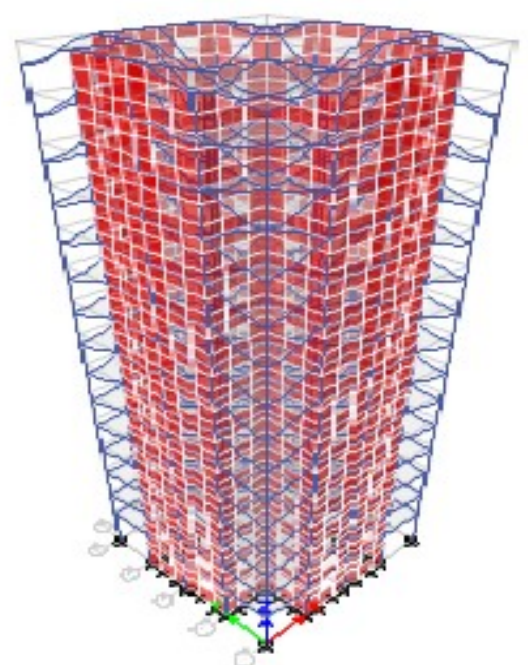

Fig. 10. 3D deflection view of infill wall of plus shape (plan) with opening

\section{RESULTS AND DISCUSSION}

\subsection{Storey Displacement}

The storey displacements were figured out for the above models and results were tabulated as follows for all models along with graphical representation.

Table 1 Displacement values of all models for Earthquake analysis using Equivalent static method (ESM) and Response spectrum

\begin{tabular}{|c|c|c|c|c|c|c|c|c|c|c|}
\hline \multirow[t]{2}{*}{$\begin{array}{l}\text { No. of } \\
\text { stories }\end{array}$} & \multicolumn{2}{|c|}{$\begin{array}{l}\text { Infill wall without } \\
\text { opening }(\mathrm{mm})\end{array}$} & \multicolumn{2}{|c|}{$\begin{array}{l}\text { Infill wall with } \\
\text { opening }(\mathrm{mm})\end{array}$} & \multicolumn{2}{|c|}{$\begin{array}{l}\text { Infill wall at } \\
\text { different } \\
(\mathrm{mm})\end{array}$} & \multicolumn{2}{|c|}{$\begin{array}{lrr}\begin{array}{l}\text { Infill } \\
\text { shape }\end{array} & \text { wall } & \begin{array}{r}\text { plus } \\
\text { (plan) }\end{array} \\
\text { without } & \text { opening } \\
(\mathrm{mm}) & & \end{array}$} & \multicolumn{2}{|c|}{$\begin{array}{l}\text { Infill wall plus } \\
\text { shape (plan) with } \\
\text { opening }(\mathrm{mm})\end{array}$} \\
\hline & ESM & RSM & ESM & RSM & ESM & RSM & ESM & RSM & ESM & RSM \\
\hline 15 & 11.9 & 10.8 & 27.5 & 24.2 & 16.2 & 13.2 & 9.5 & 7.2 & 13.0 & 10.1 \\
\hline 14 & 11.5 & 10.5 & 26.7 & 23.7 & 15.7 & 12.8 & 9.3 & 7 & 12.6 & 9.8 \\
\hline 13 & 11.1 & 10.3 & 25.9 & 23.1 & 15.1 & 12.5 & 9.0 & 6.9 & 12.1 & 9.5 \\
\hline 12 & 10.7 & 9.9 & 25.0 & 22.4 & 14.6 & 12.1 & 8.6 & 6.6 & 11.5 & 9.1 \\
\hline 11 & 10.2 & 9.6 & 23.9 & 21.7 & 13.2 & 11.2 & 8.0 & 6.3 & 10.8 & 8.7 \\
\hline 10 & 9.7 & 9.2 & 22.7 & 20.8 & 12.6 & 10.7 & 7.5 & 5.9 & 10.0 & 8.1 \\
\hline 9 & 9.2 & 8.8 & 21.5 & 19.9 & 11.8 & 10.2 & 6.8 & 5.4 & 9.1 & 7.5 \\
\hline 8 & 8.6 & 8.4 & 20.2 & 18.9 & 10.2 & 9 & 6.1 & 4.9 & 8.1 & 6.8 \\
\hline 7 & 8.1 & 7.9 & 18.4 & 17.9 & 9.5 & 8.4 & 5.3 & 4.4 & 7.1 & 6 \\
\hline 6 & 7.5 & 7.5 & 17.3 & 16.7 & 8.7 & 7.9 & 4.5 & 3.8 & 6.0 & 5.2 \\
\hline 5 & 6.8 & 6.9 & 15.9 & 15.6 & 6.9 & 6.4 & 3.7 & 3.1 & 5.0 & 4.3 \\
\hline 4 & 6.2 & 6.4 & 14.4 & 14.3 & 6.3 & 5.9 & 2.8 & 2.4 & 3.9 & 3.5 \\
\hline 3 & 5.6 & 5.8 & 12.8 & 13 & 5.6 & 5.3 & 2.0 & 1.7 & 2.9 & 2.6 \\
\hline 2 & 4.9 & 5.2 & 10.7 & 11.5 & 3.7 & 3.6 & 1.2 & 1.1 & 1.8 & 1.7 \\
\hline Gf & 4.1 & 4.5 & 9.3 & 9.8 & 3.0 & 3 & 0.5 & .5 & 0.9 & .8 \\
\hline
\end{tabular}




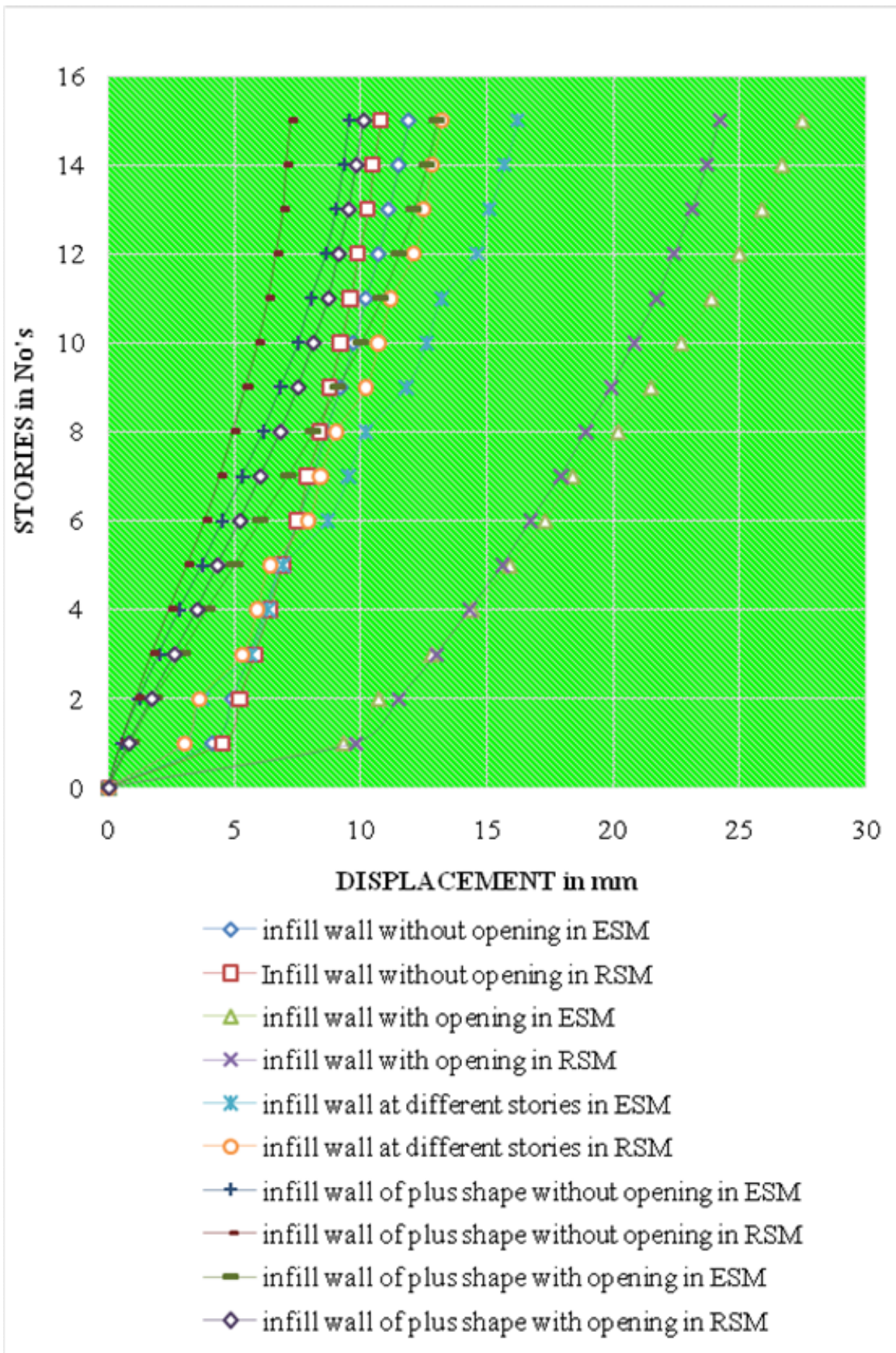

Fig.11. Variation of displacement of all models for Earthquake Analysis using Equivalent static method (ESM) and Response spectrum method (RSM)

The result shown in table 1 . gives the displacement values of all models for earthquake analysis using equivalent static method and response spectrum method. The displacement values obtained by response spectrum method is lower than that of equivalent static method. The value of displacement is less in lower storeys and it increases as the number of stories increases in equivalent static method and response spectrum method.

Fig.11. showing variation of displacement of all models for earthquake analysis using equivalent static method and response spectrum method, from fig.11. it is known that infill wall with opening in equivalent static method has higher displacement than infill wall with opening in response spectrum method. From fig.11. Infill wall at different stories in equivalent static method and response spectrum method shows a sudden increase of displacement value in stories where infill wall is not provided. Infill wall having plus shape (plan) without opening in response spectrum method shows lesser value of displacement compared to all other models. 
Table 2 Displacement values of all models for Wind analysis using Equivalent static method (ESM) and Response spectrum method (RSM)

\begin{tabular}{|c|c|c|c|c|c|c|c|c|c|c|}
\hline \multirow[t]{2}{*}{$\begin{array}{l}\text { No. of } \\
\text { stories }\end{array}$} & \multicolumn{2}{|c|}{$\begin{array}{l}\text { Infill wall without } \\
\text { opening }(\mathrm{mm})\end{array}$} & \multicolumn{2}{|c|}{$\begin{array}{l}\text { Infill wall with } \\
\text { opening (mm) }\end{array}$} & \multicolumn{2}{|c|}{$\begin{array}{l}\text { Infill wall at } \\
\text { different stories } \\
(\mathrm{mm})\end{array}$} & \multicolumn{2}{|c|}{$\begin{array}{l}\text { Infill wall plus } \\
\text { shape (plan) } \\
\text { without opening } \\
(\mathrm{mm})\end{array}$} & \multicolumn{2}{|c|}{$\begin{array}{l}\text { Infill wall plus } \\
\text { shape (plan) with } \\
\text { opening }(\mathrm{mm})\end{array}$} \\
\hline & ESM & RSM & ESM & RSM & ESM & RSM & ESM & RSM & ESM & RSM \\
\hline 15 & 2.3 & 10.8 & 2.5 & 24.2 & 4 & 2.4 & 1.8 & 7.2 & 2.9 & 10.1 \\
\hline 14 & 2.2 & 10.5 & 2.4 & 23.7 & 3.9 & 2.3 & 1.8 & 7 & 2.8 & 9.8 \\
\hline 13 & 2.2 & 10.3 & 2.4 & 22.9 & 3.8 & 2.3 & 1.7 & 6.9 & 2.7 & 9.5 \\
\hline 12 & 2.1 & 10 & 2.3 & 22.4 & 3.7 & 2.2 & 1.7 & 6.6 & 2.6 & 9.1 \\
\hline 11 & 2.1 & 9.6 & 2.2 & 21.7 & 3.5 & 2 & 1.6 & 6.3 & 2.5 & 8.7 \\
\hline 10 & 2 & 9.3 & 2.1 & 20.8 & 3.4 & 2 & 1.5 & 5.9 & 2.4 & 8.1 \\
\hline 9 & 1.9 & 8.8 & 2 & 19.9 & 3.2 & 1.9 & 1.4 & 5.4 & 2.2 & 7.5 \\
\hline 8 & 1.8 & 8.4 & 1.9 & 18.9 & 2.9 & 1.6 & 1.3 & 4.9 & 2 & 6.8 \\
\hline 7 & 1.7 & 8 & 1.8 & 17.9 & 2.7 & 1.5 & 1.2 & 4.4 & 1.8 & 6 \\
\hline 6 & 1.6 & 7.5 & 1.7 & 16.7 & 2.6 & 1.4 & 1 & 3.8 & 1.6 & 5.2 \\
\hline 5 & 1.5 & 7 & 1.6 & 14.7 & 2.1 & 1.2 & .9 & 3.1 & 1.3 & 4.3 \\
\hline 4 & 1.4 & 6.4 & 1.5 & 13.9 & 1.9 & 1.1 & .7 & 2.4 & 1.1 & 3.5 \\
\hline 3 & 1.3 & 5.8 & 1.3 & 12.6 & 1.8 & 1 & .5 & 1.7 & .8 & 2.6 \\
\hline 2 & 1.1 & 5.2 & 1.2 & 11.5 & 1.2 & .7 & .3 & 1.1 & .5 & 1.7 \\
\hline Gf & 1 & 4.5 & 1 & 9.8 & 1 & .5 & .1 & .5 & .3 & .8 \\
\hline
\end{tabular}

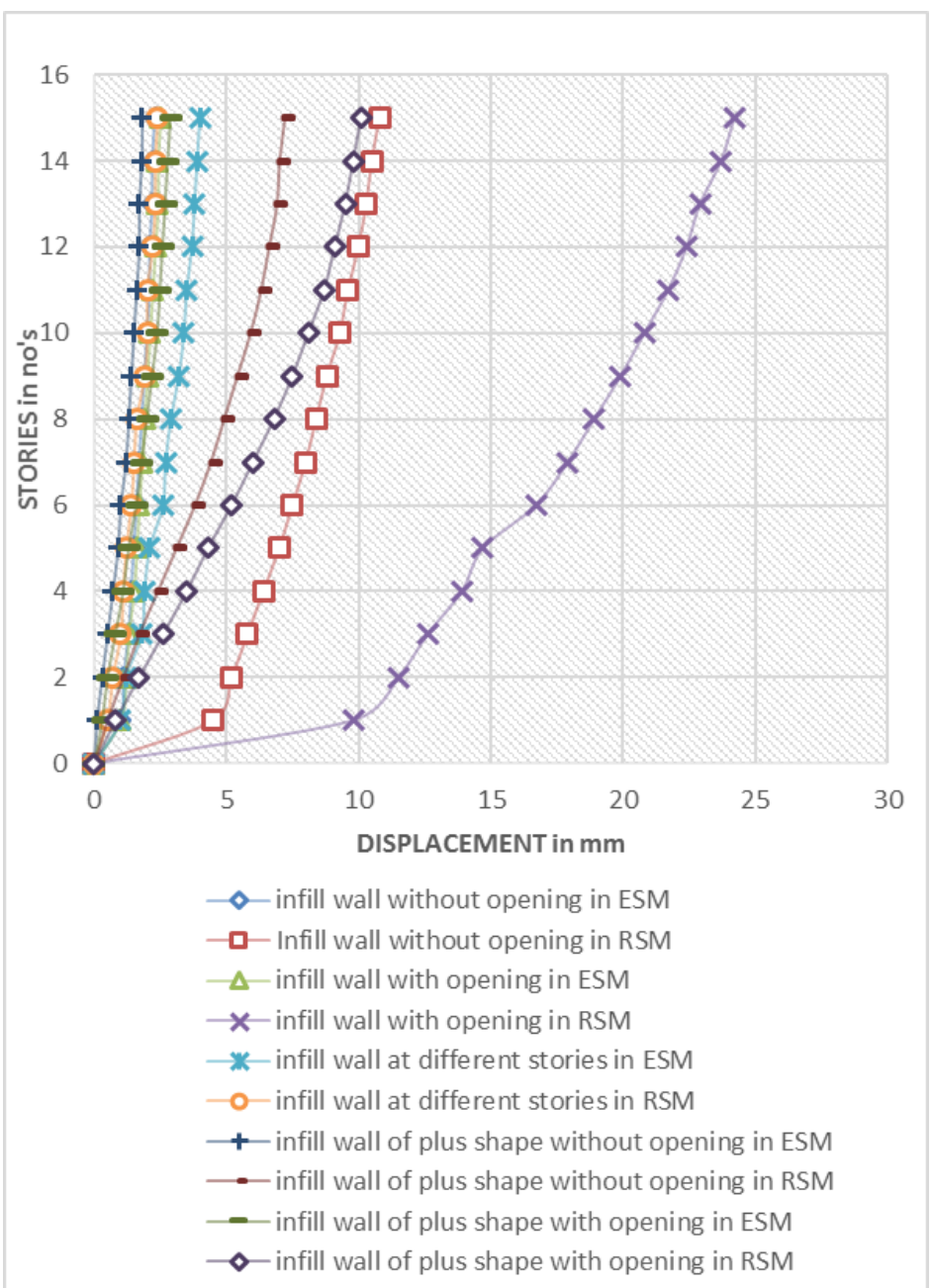

Fig.12. Variation of displacement of all models for Wind Analysis using Equivalent static method (ESM) and Response spectrum method (RSM) 
The result shown in table 2. gives the displacement values of all models for earthquake analysis using equivalent static method and response spectrum method. The value of displacement is less in lower storeys and it increases as the number of stories increases in all the five models.

Fig.12. showing variation of displacement of all five models for wind analysis using equivalent static method and response spectrum method. From fig.12. it shows that the infill wall with opening in response spectrum method has more displacement compared to all other models. From the fig, infill wall at different stories shows there is sudden increase of displacement value in stories $(3,6,9,12)$ where infill wall is not provided in lower stories and shows lesser variation of displacement value in upper stories where infill wall is not provided. Infill wall of plus shape without opening shows lesser value of displacement value compared to all other models.

\subsection{Story Drift}

The storey drift are computed for the models and is tabulated as follows along with the graphical representation.

Table 3 Drift values of all models for Earthquake analysis using Equivalent static method (ESM) and Response spectrum method (RSM)

\begin{tabular}{|c|c|c|c|c|c|c|c|c|c|c|}
\hline \multirow[t]{2}{*}{$\begin{array}{l}\text { No. of } \\
\text { stories }\end{array}$} & \multicolumn{2}{|c|}{$\begin{array}{l}\text { Infill wall without } \\
\text { opening }(\mathrm{mm})\end{array}$} & \multicolumn{2}{|c|}{$\begin{array}{l}\text { Infill wall with } \\
\text { opening }(\mathrm{mm})\end{array}$} & \multicolumn{2}{|c|}{$\begin{array}{l}\text { Infill wall at different } \\
\text { stories }(\mathrm{mm})\end{array}$} & \multicolumn{2}{|c|}{$\begin{array}{l}\text { Infill wall plus shape } \\
\text { (plan) without opening } \\
(\mathrm{mm})\end{array}$} & \multicolumn{2}{|c|}{$\begin{array}{l}\text { Infill wall plus shape } \\
\text { (plan) with opening } \\
(\mathrm{mm})\end{array}$} \\
\hline & ESM & RSM & ESM & RSM & ESM & RSM & ESM & RSM & ESM & RSM \\
\hline 15 & 0.000116 & 0.000085 & 0.000247 & 0.000184 & 0.000169 & 0.000117 & 0.000083 & 0.000050 & 0.000134 & 0.000087 \\
\hline 14 & 0.000127 & 0.000092 & 0.000277 & 0.000204 & 0.000179 & 0.000124 & 0.000107 & 0.000065 & 0.000163 & 0.000107 \\
\hline 13 & 0.000141 & 0.000102 & 0.000316 & 0.000232 & 0.000196 & 0.000136 & 0.000139 & 0.000087 & 0.000200 & 0.000134 \\
\hline 12 & 0.000156 & 0.000113 & 0.000354 & 0.000262 & 0.000437 & 0.000307 & 0.000170 & 0.000110 & 0.000237 & 0.000162 \\
\hline 11 & 0.000168 & 0.000124 & 0.000389 & 0.000291 & 0.000230 & 0.000164 & 0.000198 & 0.000132 & 0.000270 & 0.000189 \\
\hline 10 & 0.000179 & 0.000135 & 0.000418 & 0.000318 & 0.000236 & 0.000170 & 0.000221 & 0.000153 & 0.000298 & 0.000215 \\
\hline 9 & 0.000187 & 0.000145 & 0.000442 & 0.000343 & 0.000555 & 0.000421 & 0.000241 & 0.000172 & 0.000320 & 0.000237 \\
\hline 8 & 0.000194 & 0.000154 & 0.000462 & 0.000366 & 0.000241 & 0.000182 & 0.000255 & 0.000189 & 0.000337 & 0.000257 \\
\hline 7 & 0.000200 & 0.000163 & 0.000481 & 0.000387 & 0.000243 & 0.000187 & 0.000267 & 0.000204 & 0.000348 & 0.000274 \\
\hline 6 & 0.000205 & 0.000172 & 0.000489 & 0.000407 & 0.000599 & 0.000497 & 0.000274 & 0.000216 & 0.000355 & 0.000288 \\
\hline 5 & 0.000209 & 0.000181 & 0.000501 & 0.000427 & 0.000227 & 0.000185 & 0.000278 & 0.000226 & 0.000357 & 0.000298 \\
\hline 4 & 0.000215 & 0.000192 & 0.000514 & 0.000451 & 0.000228 & 0.000189 & 0.000276 & 0.000230 & 0.000352 & 0.000302 \\
\hline 3 & 0.000227 & 0.000210 & 0.000545 & 0.000494 & 0.000610 & 0.000560 & 0.000266 & 0.000227 & 0.000341 & 0.000299 \\
\hline 2 & 0.000257 & 0.000247 & 0.000563 & 0.000578 & 0.000241 & 0.000219 & 0.000234 & 0.000204 & 0.000308 & 0.000276 \\
\hline Gf & 0.001030 & 0.001116 & 0.002336 & 0.002448 & 0.000754 & 0.000742 & 0.000128 & 0.000113 & 0.000227 & 0.000085 \\
\hline
\end{tabular}




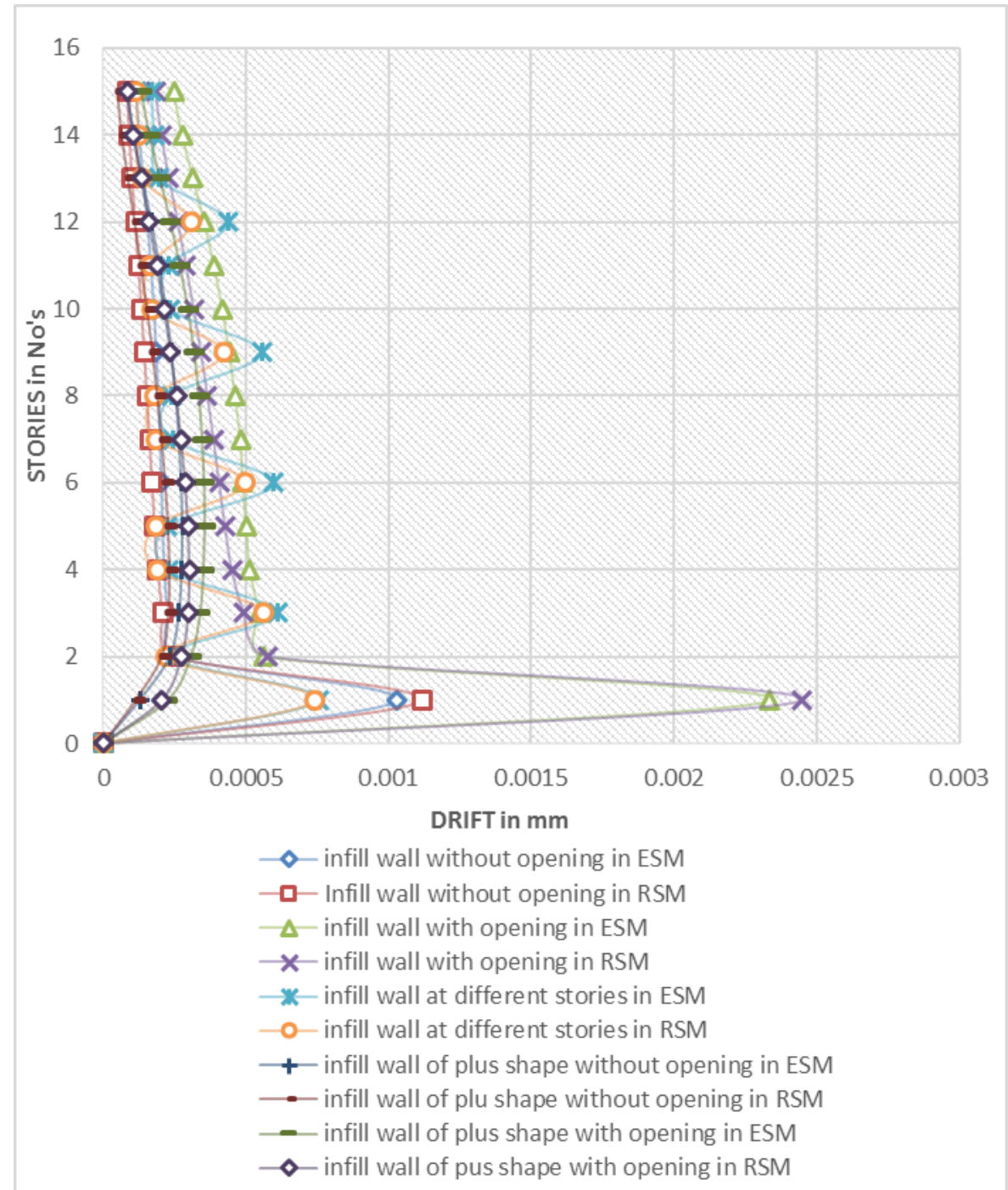

Fig.13. Variation of drift of all models for Earthquake Analysis using Equivalent static method (ESM) and Response spectrum method (RSM)

The result shown in table 3 gives the drift value of all the models for earthquake analysis using equivalent static analysis and response spectrum method. From fig.13. it shows that the drift value is considerably decreasing as the no. of stories increases. Infill wall with opening in equivalent static analysis has higher drift compared to response spectrum method for all models. The value of drift increases suddenly in stories $(3,6,9,12$,) where infill wall is not provided. Infill wall of plus shape without opening has lower drift in response spectrum method compared to all other models.

Table 4 Drift values of all models for Wind analysis using Equivalent static method (ESM) and Response spectrum method (RSM)

\begin{tabular}{|l|l|l|l|l|l|l|l|l|l|l|}
\hline $\begin{array}{l}\text { No. of } \\
\text { stories }\end{array}$ & \multicolumn{2}{l|}{$\begin{array}{l}\text { Infill wall without } \\
\text { opening }(\mathrm{mm})\end{array}$} & \multicolumn{2}{l|}{$\begin{array}{l}\text { Infill wall with } \\
\text { opening }(\mathrm{mm})\end{array}$} & \multicolumn{2}{l}{$\begin{array}{l}\text { Infill wall at } \\
\text { different stories } \\
(\mathrm{mm})\end{array}$} & \multicolumn{2}{l}{$\begin{array}{l}\text { Infill wall plus shape } \\
\text { (plan) without } \\
\text { opening }(\mathrm{mm})\end{array}$} & $\begin{array}{l}\text { Infill wall plus shape } \\
\text { (plan) with opening } \\
(\mathrm{mm})\end{array}$ \\
\cline { 2 - 13 } & ESM & RSM & ESM & RSM & ESM & RSM & ESM & RSM & ESM & RSM \\
\hline 15 & 0.000017 & 0.000086 & 0.000019 & 0.000184 & 0.000032 & 0.000020 & 0.000010 & 0.000050 & 0.000020 & 0.000087 \\
\hline 14 & 0.000018 & 0.000093 & 0.000020 & 0.000204 & 0.000034 & 0.000021 & 0.000013 & 0.000065 & 0.000025 & 0.000107 \\
\hline 13 & 0.000020 & 0.000103 & 0.000023 & 0.000241 & 0.000036 & 0.000023 & 0.000018 & 0.000087 & 0.000032 & 0.000134 \\
\hline 12 & 0.000023 & 0.000114 & 0.000025 & 0.000262 & 0.000077 & 0.000052 & 0.000024 & 0.000110 & 0.000039 & 0.000162 \\
\hline 11 & 0.000025 & 0.000125 & 0.000028 & 0.000291 & 0.000045 & 0.000029 & 0.000029 & 0.000132 & 0.000047 & 0.000189 \\
\hline
\end{tabular}




\begin{tabular}{|l|l|l|l|l|l|l|l|l|l|l|}
\hline 10 & 0.000027 & 0.000135 & 0.000030 & 0.000318 & 0.000047 & 0.000030 & 0.000035 & 0.000153 & 0.000055 & 0.000215 \\
\hline 9 & 0.000029 & 0.000145 & 0.000033 & 0.000343 & 0.000116 & 0.000074 & 0.000040 & 0.000172 & 0.000062 & 0.000237 \\
\hline 8 & 0.000031 & 0.000155 & 0.000035 & 0.000366 & 0.000052 & 0.000033 & 0.000045 & 0.000189 & 0.000069 & 0.000257 \\
\hline 7 & 0.000033 & 0.000164 & 0.000038 & 0.000387 & 0.000054 & 0.000033 & 0.000050 & 0.000204 & 0.000075 & 0.000274 \\
\hline 6 & 0.000035 & 0.000172 & 0.000040 & 0.000407 & 0.000149 & 0.000090 & 0.000055 & 0.000216 & 0.000081 & 0.000288 \\
\hline 5 & 0.000038 & 0.000181 & 0.000042 & 0.000439 & 0.000057 & 0.000034 & 0.000059 & 0.000226 & 0.000086 & 0.000298 \\
\hline 4 & 0.000040 & 0.000192 & 0.000045 & 0.000469 & 0.000058 & 0.000034 & 0.000062 & 0.000230 & 0.000090 & 0.000302 \\
\hline 3 & 0.000044 & 0.000210 & 0.000050 & 0.000486 & 0.000180 & 0.000103 & 0.000063 & 0.000227 & 0.000092 & 0.000299 \\
\hline 2 & 0.000053 & 0.000248 & 0.000059 & 0.000578 & 0.000072 & 0.000040 & 0.000058 & 0.000204 & 0.000088 & 0.000276 \\
\hline Gf & 0.000247 & 0.001116 & 0.000254 & 0.002448 & 0.000255 & 0.000137 & 0.000033 & 0.000113 & 0.000068 & 0.000206 \\
\hline
\end{tabular}

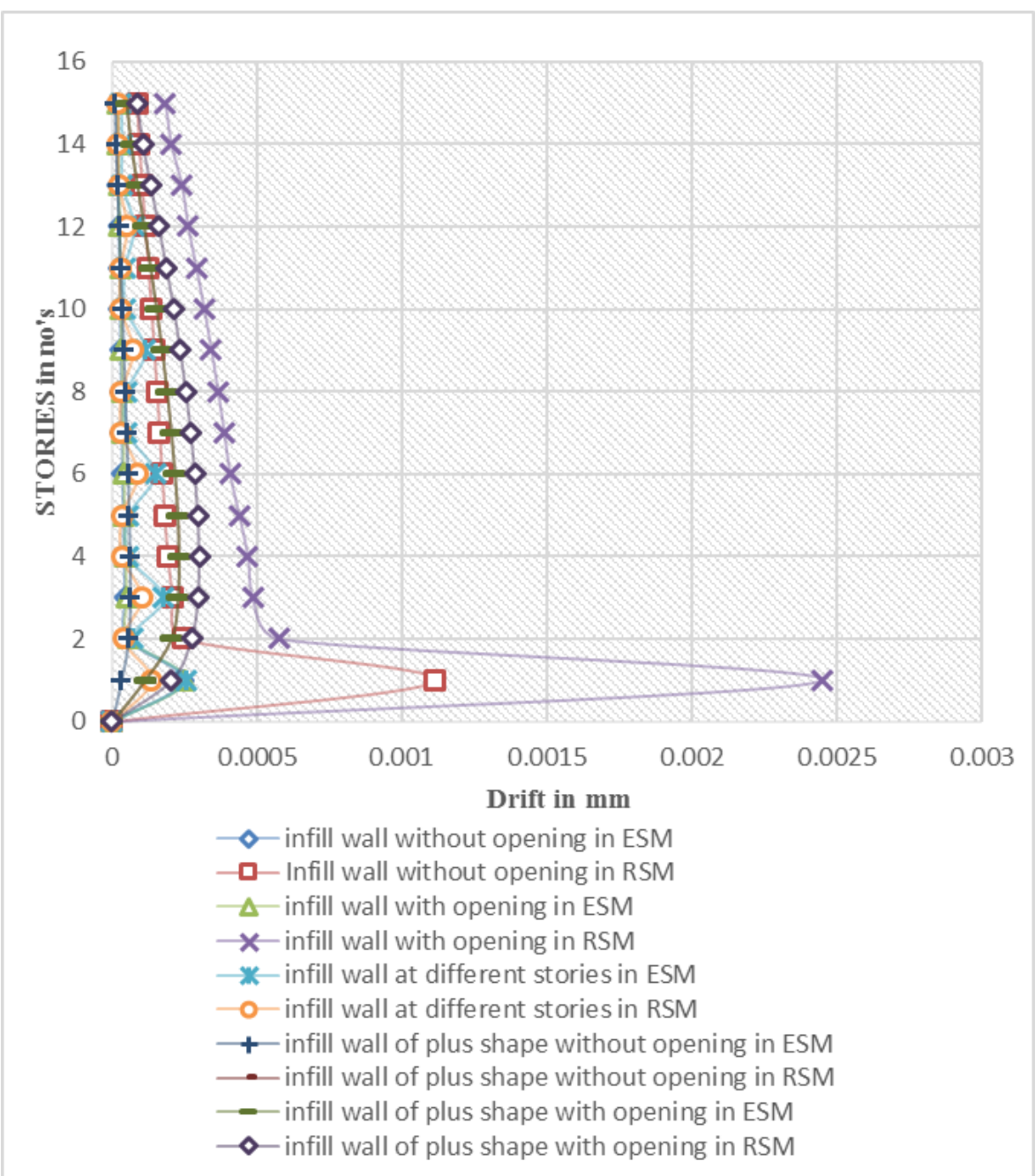

Fig.14. Variation of drift of all models for wind Analysis using Equivalent static method (ESM) and Response spectrum method (RSM)

The result shown in table 4 gives the drift values of all five model for wind analysis using equivalent static method and response spectrum method. The value of drift decreases as the no. of storeys increases in all all five models. Fig.14. showing variation of drift of all five models using equivalent static method and response spectrum method for wind load. From fig.14. it shows that the infill wall with opening in response spectrum method is more compared to all other models. From fig infill wall at different stories shows there is sudden increase of drift value in stories where infill wall is not provided in lower stories and shows lesser variation of drift value in upper stories where infill wall is not provided. Infill wall of plus shape without opening in equivalent static analysis shows lesser value of drift value compared to all other models. 


\subsection{Time History Analysis}

Table 5 Displacement values of all models for Earthquake analysis using Response spectrum method (RSM) and Time history analysis (THA)

\begin{tabular}{|c|c|c|c|c|c|c|c|c|c|c|}
\hline \multirow[t]{2}{*}{ Stories } & \multicolumn{2}{|c|}{$\begin{array}{l}\text { Infill wall } \\
\text { without } \\
\text { opening } \\
(\mathrm{mm}) \\
\end{array}$} & \multicolumn{2}{|c|}{$\begin{array}{lcc}\text { Infill } & \text { wall } & \text { with } \\
\text { opening } & (\mathrm{mm}) & \end{array}$} & \multicolumn{2}{|c|}{$\begin{array}{l}\text { Infill wall at different } \\
\text { stories }(\mathrm{mm})\end{array}$} & \multicolumn{2}{|c|}{$\begin{array}{l}\text { Infill wall of plus } \\
\text { shape without } \\
\text { opening (mm) }\end{array}$} & \multicolumn{2}{|c|}{$\begin{array}{l}\text { Infill wall of plus shape } \\
\text { with opening (mm) }\end{array}$} \\
\hline & RSM & THA & RSM & THA & RSM & THA & RSM & THA & RSM & THA \\
\hline 15 & 10.8 & 6.3 & 24.2 & 0.1000 & 13.2 & 0.04765 & 7.2 & 0.8 & 10.1 & 0.00572 \\
\hline 14 & 10.5 & 6.2 & 23.7 & 0.1000 & 12.8 & 0.04640 & 7.0 & 0.8 & 9.8 & 0.005578 \\
\hline 13 & 10.3 & 6.0 & 23.1 & 0.1000 & 12.5 & 0.04507 & 6.9 & 0.8 & 9.5 & 0.005347 \\
\hline 12 & 9.9 & 5.9 & 22.4 & 0.1000 & 12.1 & 0.04362 & 6.6 & 0.7 & 9.1 & 0.004873 \\
\hline 11 & 9.6 & 5.7 & 21.7 & 0.1000 & 11.2 & 0.04043 & 6.3 & 0.7 & 8.7 & 0.004924 \\
\hline 10 & 9.2 & 5.4 & 20.8 & 0.1000 & 10.7 & 0.03869 & 5.9 & 0.7 & 8.1 & 0.00451 \\
\hline 9 & 8.8 & 5.2 & 19.9 & 0.1000 & 10.2 & 0.03688 & 5.4 & 0.6 & 7.5 & 0.004255 \\
\hline 8 & 8.4 & 5.0 & 18.9 & 0.04907 & 9.0 & 0.03240 & 4.9 & 0.6 & 6.8 & 0.003774 \\
\hline 7 & 7.9 & 4.7 & 17.9 & 0.04643 & 8.4 & 0.03045 & 4.4 & 0.5 & 6.0 & 0.003288 \\
\hline 6 & 7.5 & 4.4 & 16.7 & 0.04360 & 7.9 & 0.02844 & 3.8 & 0.4 & 5.2 & 0.002959 \\
\hline 5 & 6.9 & 4.1 & 15.6 & 0.04058 & 6.4 & 0.02306 & 3.1 & 0.4 & 4.3 & 0.002369 \\
\hline 4 & 6.4 & 3.8 & 14.3 & 0.03497 & 5.9 & 0.02105 & 2.4 & 0.3 & 3.5 & 0.001860 \\
\hline 3 & 5.8 & 3.4 & 13.0 & 0.03288 & 5.3 & 0.01900 & 1.7 & 0.2 & 2.6 & 0.00104 \\
\hline 2 & 5.2 & 3.1 & 11.5 & 0.02695 & 3.6 & 0.01295 & 1.1 & 0.1 & 1.7 & 0.0007839 \\
\hline GF & 4.5 & 2.6 & 9.8 & 0.02560 & 3.0 & 0.01059 & 0.5 & 0.1 & 0.8 & 0.0003836 \\
\hline
\end{tabular}

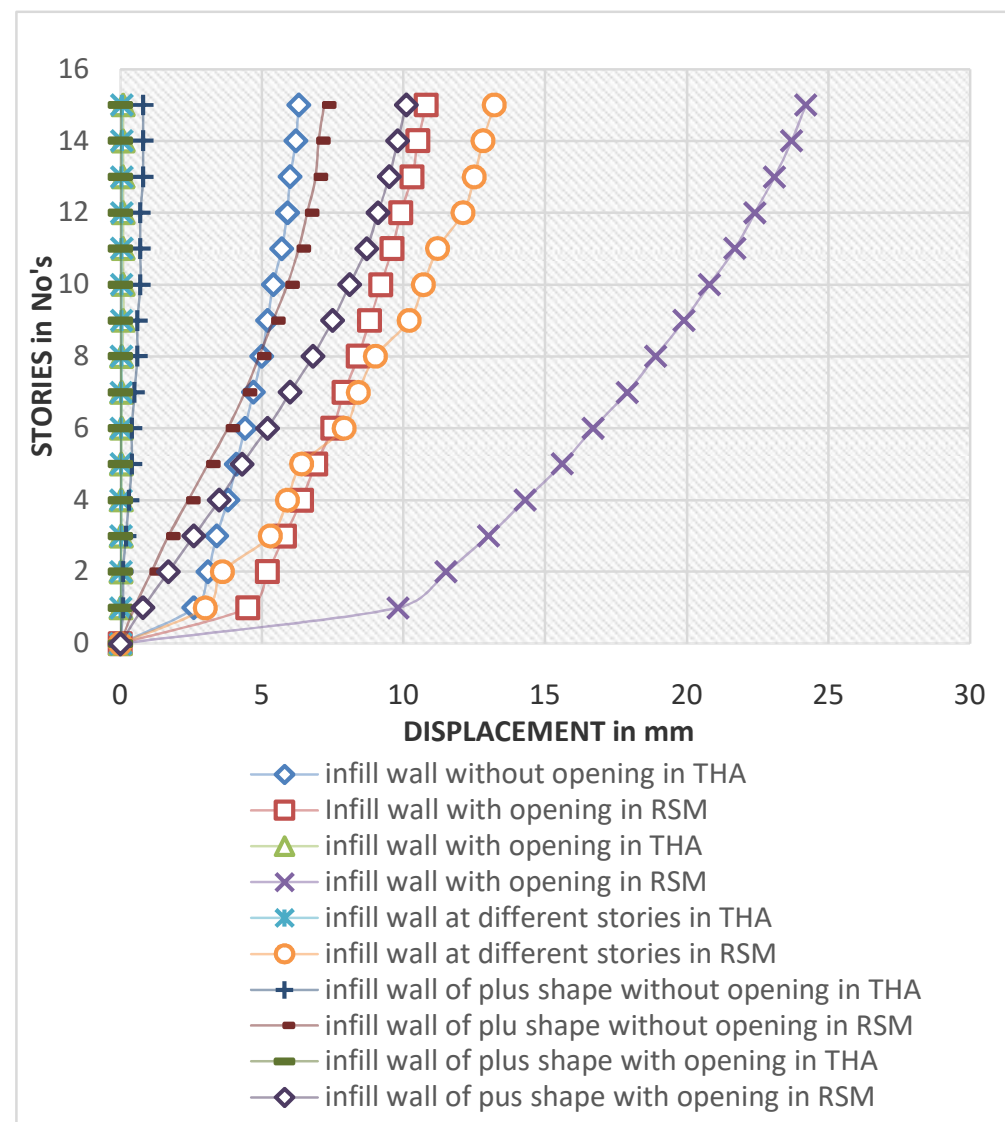

Fig 15. Variation of displacement of all models for Earthquake Analysis using Response spectrum method (RSM) and Time history analysis 
The result shown in table 5. gives the displacement values of all models for earthquake analysis using response spectrum method and time history analysis. The displacement value in response spectrum method is more than time history analysis. Fig.15. showing variation of displacement of all models for earthquake analysis using response spectrum method and time history analysis.
The value of displacement is less in lower storeys and it increases as the number of stories increases.

\subsection{Displacement V/S Time}

The time history plots of the displacement $\mathrm{v} / \mathrm{s}$ time plotted as shown in the figures below obtained for models

Table 6. Displacement value of time history of all models with time for earthquake analysis

\begin{tabular}{|l|l|l|l|l|l|}
\hline Time (sec) & $\begin{array}{l}\text { Infill wall } \\
\text { without opening } \\
\mathbf{( m m}\end{array}$ & $\begin{array}{l}\text { Infill wall with } \\
\text { opening }(\mathbf{m m})\end{array}$ & $\begin{array}{l}\text { Infill wall at } \\
\text { different stories } \\
\mathbf{( m m}\end{array}$ & $\begin{array}{l}\text { Infill wall of plus } \\
\text { shape without } \\
\text { opening (mm) }\end{array}$ & \multicolumn{2}{l}{$\begin{array}{l}\text { Infill wall of plus } \\
\text { shape with } \\
\text { opening (mm) }\end{array}$} \\
\hline 0 & 0 & 0 & 0 & 0 & 0 \\
\hline 3 & 5.3 & 0.02067 & 0.005924 & 0.000803 & 0.0007651 \\
\hline 6 & -4 & -0.03972 & -0.02637 & 0.000156 & 0.004521 \\
\hline 9 & 1.9 & -0.008106 & 0.009555 & -0.000091 & 0.0006181 \\
\hline 12 & -0.6 & 0.003725 & -0.000973 & -0.00003 & 0.000050 \\
\hline 15 & -0.3 & 0.006136 & -0.0005935 & -0.000006 & -0.0000068 \\
\hline 18 & 0.2 & 0.005039 & 0.0003233 & -0.000001 & -0.0000050 \\
\hline 21 & -0.04327 & 0.003227 & -0.0000628 & -0.000000193 & -0.0000017 \\
\hline 24 & 0.009431 & 0.001739 & -0.00000870 & -0.000000029 & -0.00000047 \\
\hline 27 & 0.0002324 & 0.0007853 & 0.00000964 & -0.000000004 & -0.00000011 \\
\hline 30 & -0.00000175 & 0.002715 & 0.00000278 & -0.000000005 & -0.0000000026 \\
\hline
\end{tabular}

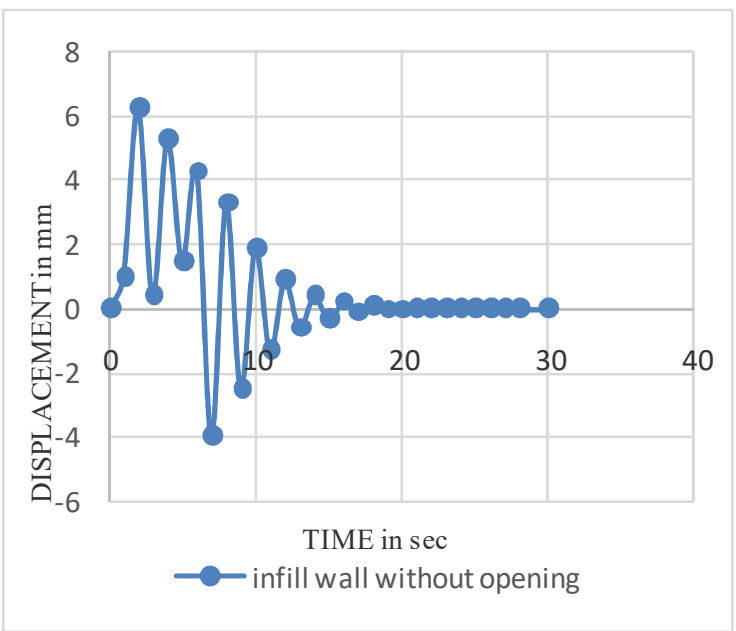

Fig.16: Variation of displacement v/s Time for infill wall without opening for earthquake analysis

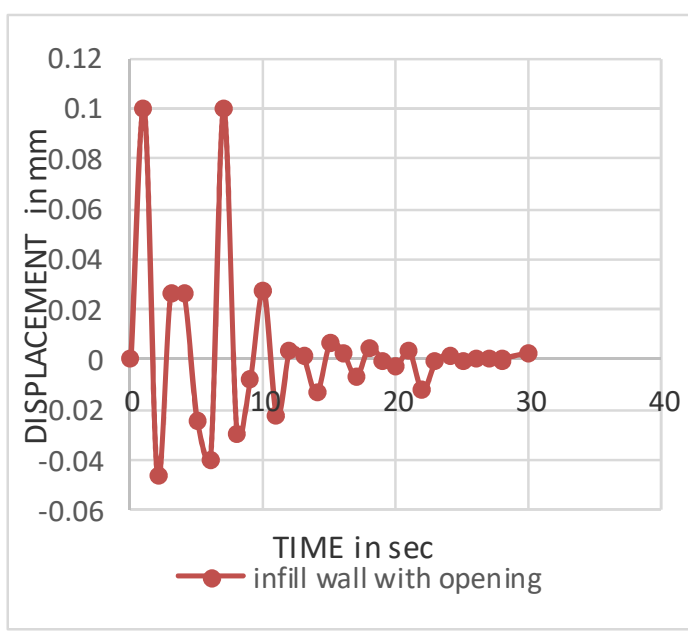

Fig.17: Variation of displacement v/s Time for infill wall with opening for earthquake analysis 


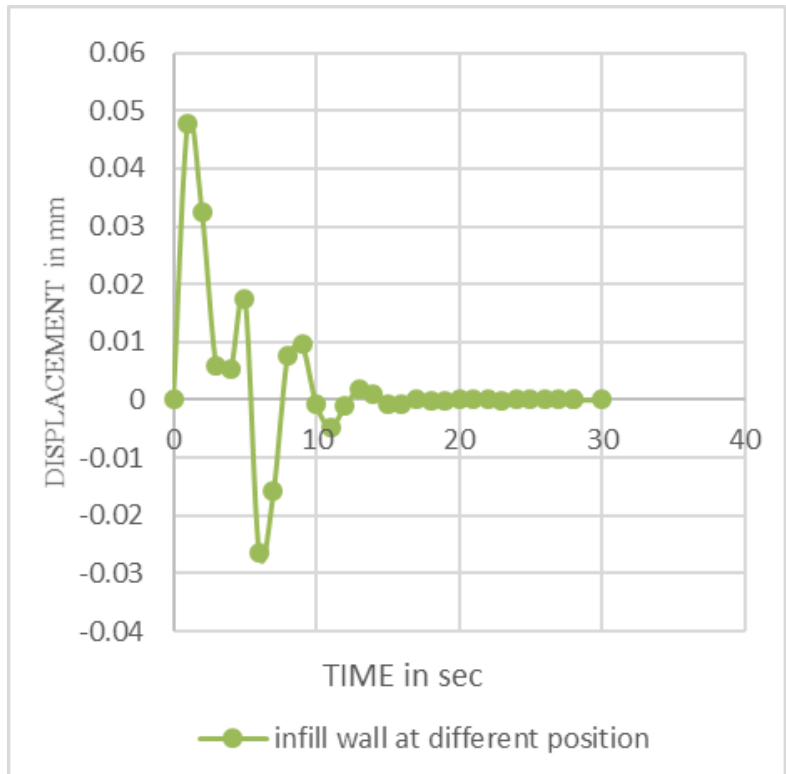

Fig.18 Variation of displacement v/s Time for infill wall at different stories for earthquake analysis wall of plus shape (plan) without opening for earthquake analysis

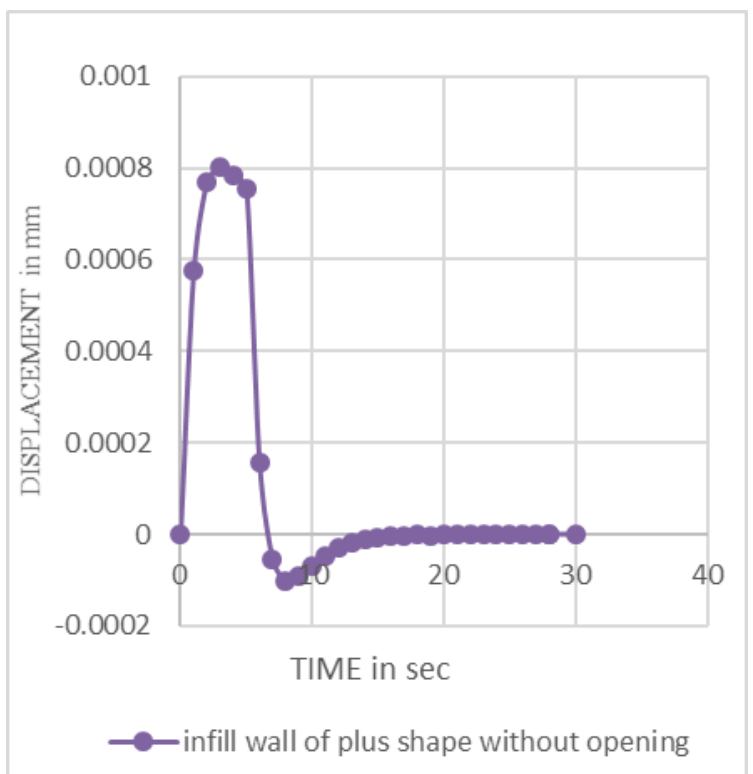

Fig.19 Variation of displacement v/s Time of infill

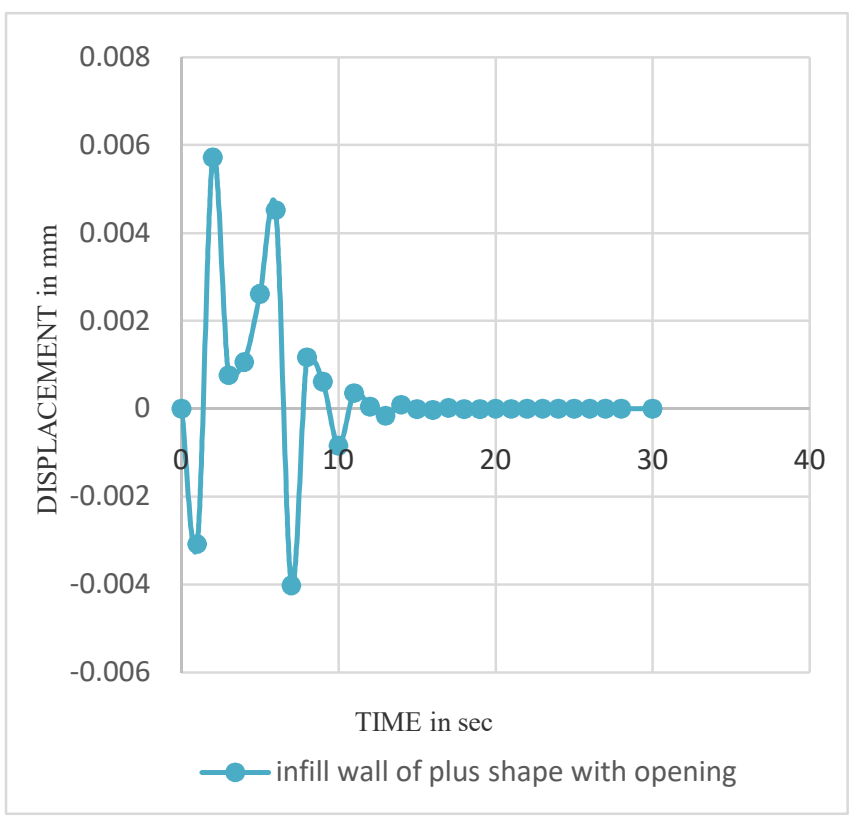

Fig.20. Variation of displacement v/s Time of infill wall of plus shape (plan) with opening for earthquake analysis

From the above table 6 and referring to the fig 16 to 20 , the results of displacement $\mathrm{v} / \mathrm{s}$ time, it is concluded that the infill wall without opening has higher displacement and are more comparable to other models. Referring to fig 16 to 20 it is also observed that there is maximum displacement of $6.3374 \mathrm{~mm}, 0.062091 \mathrm{~mm}, 0.047647$ in $1 \mathrm{sec}$ for model 1,2,3 respectively. For model 4 there is maximum displacement of $0.803 \mathrm{~mm}$ in $3 \mathrm{sec} \&$ for model 5 maximum displacement of 0.00572 in 2 sec. minimum displacement of -4.007256 in 6 sec for model $1,-0.0026739$ in $2 \mathrm{sec}$ for model $2,-0.026379$ in $6 \mathrm{sec}$ for model $3,-0.000102$ in $8 \mathrm{sec}$ for model 4, 0.004021 in $7 \mathrm{sec}$ for model5. sis . 


\section{CONCLUSION}

1. The displacements obtained for earthquake analysis using Equivalent static method are more than that of response spectrum method.

2. In Equivalent static method, the displacements obtained for infill wall with opening are more by an amount of $56.72 \%$ when compared with infill wall without opening. Hence it is concluded that minimum openings in the structure are suggested (referring fig 1)

3. Similarly in Equivalent static method the drift obtained for infill wall with opening are more by an amount of $53.03 \%$ when compared with infill wall without opening. Hence it is concluded that minimum openings in the structure are suggested (referring fig 1)

4. From fig.3. it is observed that, when infill wall at different story are provided, the drift obtained is increased by $60.4 \%$ in the story where infill wall is not provided.

5. From the result obtained, it is observed that, displacement value will be higher in the case where infill wall is not provided, hence it indicates that infill wall will play an important role in the structures.

6. Infill wall increases the strength and stiffness of the structure.

7. The displacement in structures with infill wall along with opening varies more rapidly in the initial stage and reduces subsequently.

\section{REFERENCES}

[1] Diptesh Das and C.V.R.Murty (2004) "Brick masonry infills in seismic design of RC framed buildings" Part 1- Cost implifications, The Indian Concrete Journal. July 2004, vol78 No7: 39-43.

[2] Mrugesh D. Shah May (2011) “Performance based analysis of RC frames", National Conference on Recent Trends in Engineering \& Technology

[3] Haroon Rasheed Tamboli and Umesh.N.Karadi (2012) "Seismic Analysis of RC Frame Structure with and without Masonry Infill Walls", Indian Journal of Natural Sciences International Bimonthly ISSN: 0976 - 0997 Vol.3 / Issue 14/ October 2012.

[4] Niranjan C.B. 1, M. V Renukadevi 2, K.S.Jagadish (2012) "non-linear analysis of infilled frames", IJRET: International Journal of Research in Engineering and Technology.

[5] Wakchaure M.R,Ped S.P (2013), "Earthquake analysis of high rise building with and without infilled walls", International journal of engineering and innovative Technology volume 2 , issue 2

[6] Mulgund G V et al "Seismic assesement of RC frame buildings with brick masonry infills", (IJAEST) International Journal of Advanced Engineering Sciences And Technologies Vol No. 2, Issue No. 2, $140-147$

[7] P.G.Asteris "Lateral Stiffness of Brick Masonry Infilled Plane Frames" Journal of Structural Engineering" ASCE. 